\title{
Links between Academic Motivation, Psychological Need Satisfaction in Education, and University Students' Satisfaction with Their Study
}

\author{
Melita Puklek Levpušček and Anja Podlesek \\ University of Ljubljana, Faculty of Arts, Department of Psychology, Ljubljana, Slovenia
}

\begin{abstract}
Student motivation represents an important factor in their academic performance. The present study explored university students' academic motivation across the academic year and its relationship with psychological need satisfaction in the study context and academic adjustment. Deci and Ryan's SelfDetermination Theory (SDT) presents a theoretical framework of this study. 124 students participated in both waves of data collection. They answered the Academic Motivation Scale, College Version (AMS-C 28) in the fall of the academic year, and seven months later they answered the question about their certainty of study choice and completed again the AMS-C 28. Additionally, they answered the items about their psychological need satisfaction (autonomy, competence, relatedness) in the current academic year and the items about their satisfaction with the study. The results showed that all forms of academic motivation (as distributed along the SDT motivational continuum) remained highly stable within one academic year. More autonomous motivational orientation related to higher perceived satisfaction of psychological needs. Furthermore, it significantly predicted students' satisfaction with the study and certainty about the study choice. When students' satisfaction of psychological needs in the current academic year was entered into the regression model, it predicted satisfaction with the study and certainty in study choice over and above the students' level of autonomous motivation. The study showed the importance of creating learning environments that respond to students' psychological study needs.
\end{abstract}

Keywords: tertiary education, academic motivation, basic psychological needs, study satisfaction, certainty about study choice, regression analysis

\section{Introduction}

Academic motivation is an essential component of learning at all levels of education. The research on psychological factors of academic performance consistently shows its continuing importance in study behaviour regulation also at

Melita Puklek Levpušček, Department of Psychology, Faculty of Arts, University of Ljubljana, Aškerčeva 2, 1000 Ljubljana, Slovenia. E-mail: melita.puklek@ff.uni-lj.si 
the tertiary level of education. University students' motivation that reflects an interest and enjoyment in study activities, a tendency to pursue mastery goals and focus on long-term goals, and expectations to successfully accomplish the study tasks relate to positive study outcomes, such as students' persistence in the course (Müller \& Palekčić, 2005a; Vallerand \& Bissonnette, 1992), higher certainty about the study choice and intrinsic career goals (Puklek Levpušček \& Podlesek, 2017), deep study strategies (Kusurkar, Ten Cate, Vos, Westers, \& Croiset, 2013), and higher psychological well-being, satisfaction with the study and academic performance (Burton, Lydon, D'Alessandro, \& Koestner, 2006; Müller \& Palekčić, 2005a).

\section{Academic Motivation and Self-Determination Theory}

The essential aspects of academic motivation and its influence on academic performance have been explained by different theoretical models, such as expectancy-value theory (Eccles, 1983), achievement goal theory (Ames,1992), and self-efficacy theory (Bandura, 1997; Schunk \& Pajares, 2001). Another approach which has generated a large number of studies in the field of education has been Deci and Ryan's Self-Determination Theory (SDT; Deci \& Ryan, 1985; Ryan \& Deci, 2000a, 2000b, 2017). The SDT is a humanistic theory of human motivation and personality that describes the extent to which a person's behaviour is voluntary and self-determined, i.e., to what extent people take personal control of their actions and carry them out based on their own choice. The theory is further concerned with the exploration of three basic psychological needs (relatedness, autonomy, and competence) that guide an individual's activity in different life contexts, and explores the conditions in social contexts that enhance or inhibit the satisfaction of these needs.

Students' academic motivation, as explained from the SDT perspective, ranges on a continuum from amotivation (complete absence of self-determined motivation), different types of extrinsic motivation (from higher to lower perceptions of external and internal pressures and increased feeling of self-control over one's activity) to fully self-determined (intrinsic) motivation. The motivational constructs on the SDT continuum are defined in an educational context in the following manner (Fortier, Vallerand, \& Guay, 1995; Niemiec \& Ryan, 2009): Amotivated students do not engage in an activity or they perform it automatically without any particular goal. They do not see any value in the activity, do not feel competent and do not believe in a successful outcome of the activity. The three forms of extrinsic academic motivation that follow are: external regulation (students are motivated to attain rewards or avoid negative consequences, e.g., a bad mark), introjected regulation (students engage in school work in order to satisfy internal pressures, such as to avoid feeling of guilt or to feel pride), and identified regulation (students value learning activity as important or useful to attain their personal goal and thus perform it out of choice). Intrinsic motivation represents the end point of the SDT continuum. 
Intrinsically motivated students engage in academic activities for their own sake, for the pleasure of learning something new, and without any external controls.

Some authors have assumed that intrinsic motivation can be differentiated into more specific motives (Deci, 1975; Harter, 1981). Vallerand and his collaborators (Vallerand, Blais, Brière, \& Pelletier, 1989; Vallerand et al., 1992) defined three types of intrinsic motivation (IM): "IM to know", "IM toward accomplishment", and "IM to experience stimulation". IM to know means student's engagement in activities for the sake of pleasure and satisfaction in learning, and exploring and discovering new things. IM toward accomplishment means engaging in activities for the pleasure felt when a student attempts to master the task or surpass their existent level of competence. IM to experience stimulation means engaging in activity due to positive feelings, stimulating sensations, or aesthetic enjoyment related to the activity. Validation studies which were done in different countries (e.g., Carbonneau, Vallerand, \& Lafreniere, 2012; Guay, Morin, Litalien, Valois, \& Vallerand, 2015; Puklek Levpušček \& Podlesek, 2017) confirmed the three differentiated constructs of IM. Individual differences in experiencing a certain type of IM exist because individuals are focusing on those activities that satisfy their dominant type of IM. Deci and Ryan (1985) and Ryan and Deci (2000b) further conceptualized the various forms of extrinsic motivation according to a degree an individual internalizes the initially externally regulated behaviour. With this addition, the SDT authors differentiated between autonomous motivation (i.e., intrinsic motivation and wellinternalized forms of extrinsic motivation, such as identified regulation) and controlled motivation (less-internalized forms of extrinsic motivation, such as extrinsic regulation and introjected regulation) (Ratelle, Guay, Vallerand, Larose, \& Senécal, 2007; Vansteenkiste, Lens, \& Deci, 2006). Studies in educational context suggest that autonomous motivation leads to positive academic outcomes, such as more persistence in education (Ratelle et al., 2007), greater goal progress (Koestner, Otis, Powers, Pelletier, \& Gagnon, 2008), and more positive academic self-concept and better academic achievement (e.g., Guay, Ratelle, Roy, \& Litalien, 2010). On the other hand, results on associations between controlled motivation and academic outcomes were inconsistent or showed that high levels of both autonomous and controlled motivations lead to the most adaptive academic outcomes (Ratelle et al., 2007).

To integrate the information from different motivational subscales, some SDT researchers also developed the relative autonomy index (RAI) by using unweighted or weighted motivation scale scores under one score (e.g., Fortier et al., 1995; Guay et al., 2010; Ryan \& Connell, 1989). Higher index values indicate higher autonomy or self-determined score, that is, higher expression of autonomous motivation and lower expression of controlled motivation and amotivation. In this study, we used separate motivational dimensions as well as the RAI to increase the model's parsimony in more complex analyses (Guay et al., 2010). In their recent study, Sheldon and his collaborators (Sheldon, Osin, Gordeeva, Suchkov, \& Sychev, 2017) 
validated various higher-order motivational composites (i.e., different RAI measures). They concluded that quantifying the configural relations among motivational subscales synthesizes well the information about one's overall quality of motivation. Computing the RAI may give stronger associations with well-being outcomes than using only single subscales that comprise it.

\section{Stability of Academic Motivation in Higher Education}

The stability of academic motivation dimensions along the SDT's motivational continuum has rarely been examined in higher education context. The two-year study with the US college students (Fazey \& Fazey, 1998) and the three-year follow-up study with Croatian university students (Müller \& Palekčić, 2005b) showed that motivation at the tertiary level of education is quite stable. The stabilities were found for both intrinsic and extrinsic forms of motivation, and autonomous motivation was higher than controlled motivation in both studies. High stability in academic motivation can be explained by study motives of university students (i.e., autonomous choice of study, interest in learning contents that are related to their future work) and certainty about study choice and future career which increases with student's age (Müller \& Palekčić, 2005b). Nonetheless, there is still a lack of data on the relationship between intra-individual changes in academic motivation and students' perception of their study and study goals. We might assume that students who increase their determination to the study across time also show more positive perceptions of their study and study choice.

\section{Satisfaction of Basic Psychological Needs in Higher Education}

In addition to the sparse research on change or stability of university students' academic motivation levels, there is even less information about the conditions that maintain the level of motivational dimensions in the academic context. The SDT model (Ryan \& Deci, 2000a, 2000b, 2017) postulates that humans satisfy three basic psychological needs in any social context: need for autonomy (to feel free to deliberately choose and decide upon a course of action), need for competence (to feel efficient in one's life activities), and need for relatedness (to have positive and close relations with others). According to SDT, these needs are universal and innate, and balanced satisfaction of all three needs leads to one's positive psychosocial adjustment and well-being in various social contexts, such as family, friends, education, sport, etc. In the educational domain, it is important to promote learning environments that do not press students toward outcomes but rather support task involvement and the opportunity to choose personal goals and task strategies (autonomy), offer students optimal challenge, positive feedback and informational rewards (competence), and enable students to feel accepted (relatedness). Such learning settings may facilitate the internalization of external curricular regulations. Consequently, more self-determined academic motivations develop, which in turn 
lead to better academic outcomes (Niemiec \& Ryan, 2009). Karimi and Sotoodeh (2019) and Sun, Ni, Zhao, Shen, and Wang (2018), for example, found that the satisfaction of the three basic psychological needs in university context had direct and positive effects on students' intrinsic motivation, which in turn stimulated greater academic engagement. Although SDT proposed that autonomous motivation might be sustained or it might even flourish when basic psychological needs are satisfied, there is a lack of longitudinal studies in higher education which tested this assumption. Müller and Palekčič (2005b), for example, showed that Croatian university students' motivation remains stable relatively independently of the support of autonomy and competence in the learning environment. However, students' satisfaction of relatedness need contributed to the explanation of the autonomous motivation in their cross-sectional study (Müller \& Palekčić, 2005a) as well as in their three-year longitudinal study (Müller \& Palekčić, 2005b).

\section{The Present Study}

The present study is the first investigation of the aspects of academic motivation and psychological need satisfaction, as described within the SDT perspective, in a Slovenian university context. In our recent cross-sectional study (Puklek Levpušček \& Podlesek, 2017), we got some information about the academic motivational orientations of Slovenian university students; they reached the highest scores on identified regulation, IM to know and external regulation, and a low average score on amotivation. This study aimed to further explore university students' academic motivation across the academic year, its relationship with psychological need satisfaction in the study context, and academic adjustment. Using data from two time points (fall and spring) within one academic year we aimed to find out (1) if different forms of academic motivation (intrinsic, extrinsic, and amotivation) change across an academic year, (2) how more- and less-internalized forms of academic motivation and within-person changes in autonomous motivation (as measured by the RAI) are related to the level of satisfaction of basic psychological needs (competence, autonomy, relatedness) in the academic year, and (3) how students' autonomous motivation across the academic year, its change, and psychological need satisfaction contribute to the prediction of the two indicators of academic adjustment, i.e. student's satisfaction with the study and student's certainty of study choice. Based on the SDT model and research presented above, we hypothesized that: (a) different forms of academic motivation would remain stable over the academic year, (b) students' psychological needs satisfaction in the study context will be positively correlated with well-internalized forms of academic motivation, the RAI measure and its change, and negatively related to amotivation and poorly internalized forms of extrinsic motivation, and (c) autonomous motivation and fulfilment of the psychological needs in education would be predictors of study satisfaction and students' certainty of study choice. 


\section{Method}

\section{Participants}

The initial sample at Wave 1 consisted of 201 Slovenian students at the University of Ljubljana - 68 (34\%) males and $133(66 \%)$ females - who were in their 1st year at the master level of study in the academic year 2017/18. The majority $(f=147 ; 74 \%)$ were students of social sciences and humanities, and $27 \%$ were students of natural sciences and technology. They were between 21 and 33 years old $(M=23.15, S D=1.51)$. In the second wave of data collection (Wave 2), 124 students participated, among them 44 (35\%) males and $80(65 \%)$ females; 68\% were students of social sciences and humanities. The attrition rate was $38 \%$.

\section{Instruments}

At Wave 1, the participants completed a demographic questionnaire that included questions about their chronological age, gender and study program (social sciences and humanities vs. natural sciences and technology). Participants then filled in the Academic Motivation Scale, College Version (Academic Motivation Scale, AMS-C 28, Vallerand et al., 1992). Approximately seven months later, participants answered the question about their certainty of study choice (To what extent do you believe that your study has been the right choice for your career? 1 - not at all, 5 - completely) and completed again the AMS-C 28. Additionally, they answered items about their basic psychological need satisfaction in the current academic year and items about their study satisfaction. The three scales (AMS-C 28, Basic Psychological Need Satisfaction in Education scale, and Study Satisfaction Scale) are described below.

The Academic Motivation Scale, College Version (AMS-C 28, Vallerand et al., 1992) measures a multidimensional motivational construct. The scale consists of three scales of intrinsic motivation (i.e., knowledge, accomplishment, and stimulation), three scales of external motivation (i.e., external regulation, introjected regulation, identified regulation), and one scale of amotivation. The AMS-C 28 scales reflect the SDT continuum of self-determination, with different types of motivation being ranked from high (intrinsic motivation (IM), identified regulation) to low (external regulation, amotivation) degree of self-determination. Participants are asked why they go to university, and are provided with items describing different motivational reasons, such as "For the pleasure I experience when I discover new things never seen before" (IM to know), "For the satisfaction I feel when I am in the process of accomplishing difficult academic activities" (IM toward accomplishment), "For the 'high' feeling that I experience while reading about various interesting subjects" (IM to experience stimulation), "Because I believe that a few additional years of education will improve my competence as a worker" (identified regulation), "Because I want to show myself that I can succeed in my 
studies" (introjected regulation), "In order to have a better salary later on" (external regulation), and "Honestly, I don't know; I really feel that I am wasting my time at university" (amotivation). Each scale includes four items which are rated on a 7-point scale $(1$ - Not at all true, 7 - Exactly true). Validation studies that were done in different countries confirmed good construct and convergent validity and reliability of the AMS-C 28 (Cokley, Bernard, Cunningham, \& Motoike, 2001; Fairchild, Horsta, Finneya, \& Barron, 2005; Puklek Levpušček \& Podlesek, 2017; Vallerand et al., 1992). In the present study, both the internal consistency of the scales and the test-retest reliability of the scales were adequate. Standardized alpha coefficients in Wave 1 (and Wave 2 in parentheses) were .84 (.88) for the Amotivation scale, .81 (.84) for the External Regulation scale, .83 (.82) for the Introjected Regulation scale, $.80(.79)$ for the Identified Regulation scale, $.84(.83)$ for the IM to know scale, .87 (.83) for the IM toward accomplishment scale, and $.86(.88)$ for the IM to experience stimulation scale. For the listed scales, the test-retest (Pearson correlation) coefficients were $.58, .62, .57, .42, .54, .66$, and .68 , respectively. To reduce the number of motivational dimensions and identify the amount of autonomous motivation relative to their controlled motivation and amotivation, we calculated the RAI for each participant, which was further used in more complex analyses. We used the formula proposed by Guay et al. (1995): 2 - [(IM knowledge + IM accomplishment + IM stimulation)/3] + identified regulation - external regulation + $2 \cdot$ amotivation.

We used 10 items from the Basic Psychological Need Satisfaction at Work Scale (BNSW-S; Deci et al., 2001) which measure fulfilment of the competence, autonomy, and relatedness needs in the workplace. We independently translated the items and kept the version of each translated item that both agreed on. Next, we slightly modified the translated items to measure need satisfaction in an educational context. Some examples of the modified items are the BNSW-S item "People at work tell me I am good at what I do", which measures the satisfaction of the competence need at work, was changed to "Professors tell me I am good at studying". The BNSW-S item "I really like the people I work with", which measures the satisfaction of the relatedness need at work, was changed to "I really like my student colleagues", and the BNSW-S item "I am free to express my ideas and opinions on the job", which measures the autonomy need satisfaction in the workplace, was changed to "I am free to express my ideas and opinions about my study work". We created two additional items - "I feel I can successfully accomplish even difficult study tasks" for measuring the competence need and "I work on study tasks because it is my will to do so" for measuring the autonomy need - to balance the number of items in the three scales. The final version of the questionnaire consisted of 12 items (4 items per each scale). The items were rated on a 7-point scale $(1-$ not true at all, 4 - moderately true, 7 - very true). The competence need scale measured students' feeling of competence in the study environment and positive feedback of professors, the relatedness need scale measured perceived support and friendly relationship with student colleagues, and the autonomy need scale measured their feeling of free self- 
expression, decision-making and volition in the study context. The confirmatory factor analysis using MLR estimators showed that the three-factor model marginally fitted the data, $\chi^{2}(51)=107.88, p<.001, \mathrm{CFI}=.908$, RMSEA $=.085,95 \% \mathrm{CI}$ for RMSEA $=[.063, .107]$, SRMR $=.080$, which is why we proceeded with the threefactor structure. Standardized Cronbach's alpha coefficients were .90 for the relatedness need scale (McDonald's $\omega=.92)$ and $.76(\omega=.80)$ for the competence need scale, and indicated satisfactory internal consistency of the scores on the two scales. Standardized alpha coefficient for the autonomy need scale was .68 $(\omega=.72)$ and showed somewhat less adequate reliability, but we decided to continue using this scale for our research purposes and remain cautious about its use.

Four items were created to measure students' satisfaction with their studies in the current academic year. The example item is: "I got a lot of additional knowledge and skills for my future professional work". The items were rated on a 5-point scale $(1-$ not true at all, 5 - very true $)$. The scale showed good internal consistency $(\alpha=$ $.82)$.

\section{Procedure}

We collected data twice with the same sample of participants. The first data collection (Wave 1) was held at the beginning of the academic year (October 2017) and the second data collection (Wave 2) took place in the last month of pedagogical activities at the university (May 2018). At both times, the students participated through an online survey application. Students from different departments at the Faculty of Arts, University of Ljubljana, were asked to participate and to recruit another student participant. Students who participated and found another student participant received a bonus for a course. Before starting the survey, the students provided an informed agreement to participate in the study. The survey took approximately 10-15 minutes.

\section{Results}

First, as attrition rate was high, we compared the participants who did not participate in Wave 2 (marked with A for the attrition group, $n=77$ ) with those who did participate in Wave 2 (marked with $\mathrm{P}$ for participating group, $n=124$ ). The two groups did not differ statistically significantly according to gender $(65 \%$ women in group A, 69\% women in group P; Fisher exact test $p=.544)$, age $\left(M_{\mathrm{A}}=23.32\right.$ years, $S D_{\mathrm{A}}=1.78$ years, $M_{\mathrm{P}}=23.03$ years, $S D_{\mathrm{P}}=1.30$ years, $t[127.06]=-1.24, p=.216$ ), average study grade $\left(M_{\mathrm{A}}=8.17, S D_{\mathrm{A}}=0.59, M_{\mathrm{P}}=8.28, S D_{\mathrm{P}}=0.63, t[169.06]=\right.$ $1.24, p=.218)$, Amotivation scale score $\left(M_{\mathrm{A}}=1.67, S D_{\mathrm{A}}=0.81, M_{\mathrm{P}}=1.67, S D_{\mathrm{P}}=\right.$ $0.84, t[165.59]=0.01, p=.988)$, External Regulation scale score $\left(M_{\mathrm{A}}=4.94, S D_{\mathrm{A}}=\right.$ $\left.1.27, M_{\mathrm{P}}=5.05, S D_{\mathrm{P}}=1.16, t[150.31]=0.61, p=.544\right)$, Introjected Regulation scale 
score $\left(M_{\mathrm{A}}=4.00, S D_{\mathrm{A}}=1.51, M_{\mathrm{P}}=4.02, S D_{\mathrm{P}}=1.36, t[148.40]=0.10, p=.924\right)$, Identified Regulation scale score $\left(M_{\mathrm{A}}=5.34, S D_{\mathrm{A}}=1.23, M_{\mathrm{P}}=5.55, S D_{\mathrm{P}}=0.96\right.$, $t[132.71]=1.29, p=.198)$, IM to know scale score $\left(M_{\mathrm{A}}=5.59, S D_{\mathrm{A}}=0.99, M_{\mathrm{P}}=\right.$ 5.54, $\left.S D_{\mathrm{P}}=0.96, t[157.12]=-0.32, p=.751\right)$, IM toward accomplishment scale score $\left(M_{\mathrm{A}}=4.42, S D_{\mathrm{A}}=1.38, M_{\mathrm{P}}=4.51, S D_{\mathrm{P}}=1.38, t[161.26]=0.44, p=.664\right)$, IM to experience stimulation scale score $\left(M_{\mathrm{A}}=4.48, S D_{\mathrm{A}}=1.35, M_{\mathrm{P}}=4.29, S D_{\mathrm{P}}=\right.$ $1.34, t[160.81]=-0.96, p=.339)$, and the RAI score $\left(M_{\mathrm{A}}=6.72, S D_{\mathrm{A}}=3.66, M_{\mathrm{P}}=\right.$ $\left.6.72, S D_{\mathrm{P}}=3.92, t[169.72]=0.01, p=.995\right)$. However, in the group of social sciences and humanities students, the percentage of those that quit the study (44\%) was larger than in the group of natural sciences and technology students $(25 \%)$, Fisher exact test $p=.021$.

The following analyses were done with participants having complete data $(N=$ 124). The certainty of study choice was considered an ordinal variable. All other examined variables were considered as an interval. Statistical hypotheses were tested at a 5\% alpha error rate if not listed otherwise.

As can be seen in Table 1, all academic motivation dimensions were, according to the means in both waves of data collection, quite stable from the beginning to the end of the academic year. In both waves, the three dimensions of intrinsic motivation were above the scale's midpoint, with IM to know having the highest average score. Similar to IM to know, identified regulation, as the most self-determined type of external motivation, was quite strongly present. Students also showed the aboveaverage score on the External Regulation scale, which refers to external motivation regulated by attaining positive consequences (e.g., to study in order to have better salary later on) or avoiding negative ones (e.g., to avoid having bad job opportunities later on). On the Amotivation scale, they had low average score in both waves. With regard to experiencing learning autonomy, competence and relatedness in the academic year, all three needs were perceived as being satisfied above the scale's midpoint, with relatedness being the most satisfied need in the study context as reported by students. At last, students showed high certainty of their study choice, whereas the average level of students' satisfaction with their study in Wave 2 was moderately high.

As there were no statistically significant changes in different motivation scale scores from Wave 1 to Wave 2, we calculated for each scale the average score achieved in both waves. Similarly, the RAI obtained in Wave 1 did not differ statistically significantly from the one obtained in Wave 2 (see in Table 1), which is why the average RAI (called avRAI) was calculated across both waves, indicating participants' general autonomy patterns. The difference between the Wave 2 and Wave 1 RAIs (called RAI $\Delta$ ) was calculated as well to show the change in the autonomy patterns through the study year. Positive values indicated a shift towards more self-determined (well-internalized) forms of motivation, and negative values indicated a shift towards more non-self-determined (poorly internalized) motivation constructs. Even though the average change in RAI from Wave 1 to Wave 2 was low 


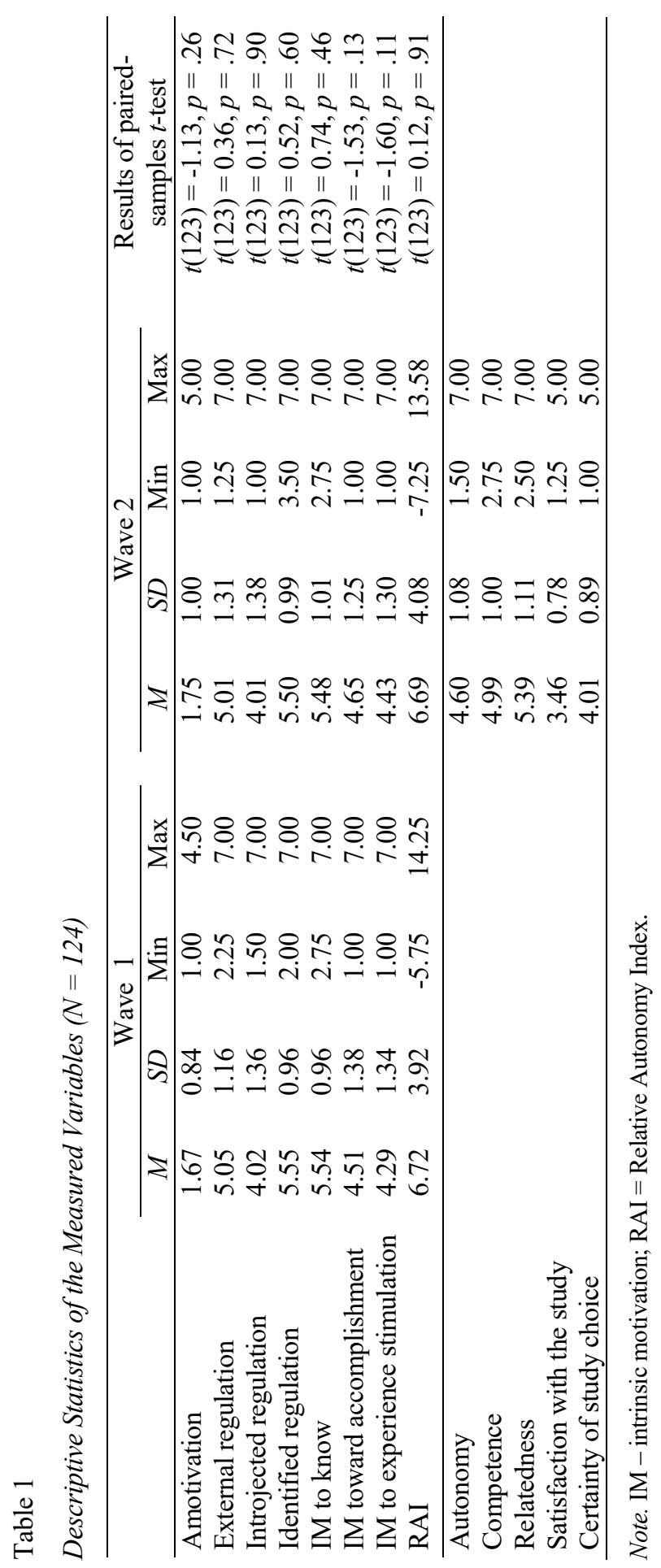


$(M=-0.03)$, relatively large variability in RAI $\Delta(S D=3.01$, Min $=-10.92$, Max $=$ 9.25) indicated that students experienced very different changes in the autonomy patterns through the study year.

Table 2

Correlations of Motivation Variables Averaged across Waves 1 and 2 with Wave 2 Psychological Need Fulfilment and Wave 2 Study Satisfaction (Pearson Coefficients), and with Wave 2 Study Choice Certainty (Spearman Coefficients)

\begin{tabular}{lccccc}
\hline & $\begin{array}{c}\text { Relatedness } \\
\text { needs } \\
\text { satisfaction }\end{array}$ & $\begin{array}{c}\text { Competence } \\
\text { needs } \\
\text { satisfaction }\end{array}$ & $\begin{array}{c}\text { Autonomy } \\
\text { needs } \\
\text { satisfaction }\end{array}$ & $\begin{array}{c}\text { Satisfaction } \\
\text { with } \\
\text { study }\end{array}$ & $\begin{array}{c}\text { Study } \\
\text { choice } \\
\text { certainty }\end{array}$ \\
\hline $\begin{array}{l}\text { Amotivation } \\
\text { External }\end{array}$ & -.23 & $-.27^{*}$ & $-.34^{* *}$ & $-.37^{* *}$ & $-.52^{* * *}$ \\
$\begin{array}{l}\text { Regulation } \\
\text { Introjected }\end{array}$ & .14 & -.05 & -.05 & .08 & .00 \\
$\begin{array}{l}\text { Regulation } \\
\text { Identified }\end{array}$ & -.05 & -.14 & -.02 & .10 & -.01 \\
$\begin{array}{l}\text { Regulation } \\
\text { IM to know }\end{array}$ & .17 & .16 & .27 & .23 & $.34^{* *}$ \\
$\begin{array}{l}\text { IM toward } \\
\text { accomplishment }\end{array}$ & .06 & .25 & .18 & .26 & $.29^{*}$ \\
$\begin{array}{l}\text { IM to experience } \\
\text { stimulation }\end{array}$ & -.02 & .17 & .22 & .29 & .22 \\
\hline
\end{tabular}

${ }^{*} p<.05 ;{ }^{* *} p<.01 ;{ }^{* * *} p<.001$. (Holm correction for multiple tests was used). IM = intrinsic motivation.

Table 2 shows correlations between seven academic motivation dimensions averaged across the two time points in the academic year and basic psychological need satisfaction in education, certainty of study choice, and students' satisfaction with their study as measured in Wave 2. The results showed that students with higher score on the Amotivation scale perceived lower satisfaction of their needs for competence and autonomy in the learning context, were less certain that their choice of study was right and were less satisfied with their study. Certainty in the study choice was additionally positively related to identified regulation and intrinsic motivation related to the motives of learning new things and broadening one's knowledge (IM to know).

Correlations between the RAI, its change during the academic year, and the Wave 2 variables (the three basic psychological needs, satisfaction with the studies, and certainty of study choice) are shown in Table 3 . The RAI correlated positively with students' fulfilment of the competence and autonomy needs in the study context, satisfaction with the study, and their certainty in study choice. Changes in the RAI across the academic year did not relate statistically significantly to any of the variables. Students' fulfilment of three basic psychological needs across the academic year was related positively to students' certainty of study choice and their study satisfaction. 
Table 3

Correlations (Pearson Coefficients) among the Average RAI (AvRAI), the Change in RAI (RAI $\Delta$ ), the Psychological Need Satisfaction, Study Satisfaction, and Certainty about Study Choice

\begin{tabular}{|c|c|c|c|c|c|c|c|}
\hline & 1 & 2 & 3 & 4 & 5 & 6 & $7^{\mathrm{a}}$ \\
\hline 1 - AvRAI & - & .06 & .11 & $.25^{*}$ & $.35^{* *}$ & $.30^{* * *}$ & $.47^{* * * *}$ \\
\hline $2-\mathrm{RAI} \Delta$ & & - & .05 & .17 & .10 & .20 & .07 \\
\hline $\begin{array}{l}3 \text { - Relatedness need } \\
\text { satisfaction }\end{array}$ & & & - & .13 & .20 & $.28^{*}$ & .20 \\
\hline $\begin{array}{l}4 \text { - Competence need } \\
\text { satisfaction }\end{array}$ & & & & - & $.33^{* *}$ & $.31^{* * *}$ & $.35^{* *}$ \\
\hline $\begin{array}{l}5 \text { - Autonomy need } \\
\text { satisfaction }\end{array}$ & & & & & - & $.57^{* * * *}$ & $.45^{* * *}$ \\
\hline $\begin{array}{l}6 \text { - Satisfaction with } \\
\text { the study }\end{array}$ & & & & & & - & $.34^{* *}$ \\
\hline $\begin{array}{l}7 \text { - Study choice } \\
\text { certainty }^{\mathrm{a}}\end{array}$ & & & & & & & - \\
\hline
\end{tabular}

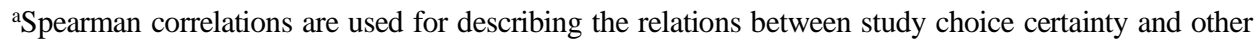
variables, because study choice certainty was considered an ordinal variable.

${ }^{*} p<.05 ;{ }^{* *} p<.01 ;{ }^{* * *} p<.001$. (Holm correction for multiple tests was used.)

The next two hierarchical regressions were done to test the assumption that better academic adjustment happens in learning contexts where students' capacities for autonomous learning are accompanied by environmental endeavours to satisfy students' basic psychological needs (e.g., Niemiec \& Ryan, 2009). First, we performed a hierarchical linear regression to find out whether self-determined academic motivation (as measured by the avRAI) and its change (RAI $\Delta$ ) during the academic year predict students' satisfaction with the study and whether students' perceptions of basic psychological need satisfaction in the current academic year predict satisfaction with the study over and above the level of self-determined motivation. In Step 1, the avRAI and the RAI $\Delta$ were entered simultaneously in the regression model. In Step 2, satisfaction of the basic psychological needs were additionally entered in the model. The results of the analysis are shown in Table 4. In Step 1, both average autonomy index (avRAI) and change in this index (RAI $\Delta$ ) statistically significantly predicted satisfaction with the study. The higher the autonomy and the larger the shift towards more self-determined motivation during the academic year, the more satisfied the students were on average with the study. In Step 2, however, these two predictors lost some of their predictive power and became statistically insignificant when variables related to the satisfaction of basic psychological needs were entered in the regression model. As the RAI shared some variance with the autonomy need satisfaction (see Table 3) - students who reported 
of more self-determined (well-internalized) forms of motivation, also reported on average of higher satisfaction of the autonomy need - entering the autonomy need satisfaction into the model took away some of the predictive power from the avRAI and RAI $\Delta$. The strongest predictor in the final model was the satisfaction of the autonomy need, followed by the satisfaction of the relatedness need. This might

Table 4

Results of Hierarchical Linear Regression for Predicting Satisfaction with the Studies

\begin{tabular}{lcccccr}
\hline Predictor & $b$ & $S E_{\mathrm{b}}$ & $\beta$ & $t$ & $p$ & $95 \% \mathrm{CI}$ for $b$ \\
\hline Step 1: adjusted $R^{2}=.11, F(2,121)=8.66, p<.001$ & & & \\
\hline Intercept & 3.05 & 0.13 & & 22.21 & $<.001$ & {$[2.779,3.323]$} \\
AvRAI & 0.06 & 0.02 & 0.29 & 3.44 & $<.001$ & {$[0.026,0.097]$} \\
RAI $\Delta$ & 0.05 & 0.02 & 0.18 & 2.15 & .034 & {$[0.004,0.091]$} \\
\hline Step 2: adjusted $R^{2}=.37, F(5,118)=15.18, p<.001 ; \Delta R^{2}=.26, F(3,118)$ & $=17.21, p<.001$ \\
\hline Intercept & 0.84 & 0.39 & \multicolumn{5}{c}{2.12} & .036 & {$[0.054,1.617]$} \\
AvRAI & 0.02 & 0.02 & 0.09 & 1.19 & .238 & {$[-0.013,0.052]$} \\
RAI $\Delta$ & 0.03 & 0.02 & 0.13 & 1.73 & .086 & {$[-0.005,0.070]$} \\
Relatedness need satisfaction & 0.11 & 0.05 & 0.16 & 2.13 & .035 & {$[0.008,0.212]$} \\
Competence need satisfaction & 0.07 & 0.06 & 0.09 & 1.16 & .250 & {$[-0.050,0.190]$} \\
Autonomy need satisfaction & 0.34 & 0.06 & 0.47 & 5.81 & $<.001$ & {$[0.223,0.453]$} \\
\hline
\end{tabular}

Table 5

Results of Hierarchical Ordinal Regression for Predicting Certainty in the Study Choice

\begin{tabular}{|c|c|c|c|c|c|c|}
\hline Predictor & $b$ & $S E_{\mathrm{b}}$ & $t$ & $p$ & OR & $\begin{array}{c}95 \% \text { CI for } \\
\text { OR }^{\mathrm{a}}\end{array}$ \\
\hline \multicolumn{7}{|c|}{ Step 1: $-2 \mathrm{LL}=271.06, \mathrm{AIC}=283.06, \chi^{2}(2)=31.39, p<.001$, Nagelkerke $R^{2}=.25$} \\
\hline Threshold $1 \mid 2$ & -2.97 & 0.75 & -3.96 & $<.001$ & & \\
\hline Threshold $2 \mid 3$ & -1.80 & 0.48 & -3.74 & $<.001$ & & \\
\hline Threshold $3 \mid 4$ & 0.34 & 0.37 & 0.92 & .358 & & \\
\hline Threshold $4 \mid 5$ & 2.69 & 0.45 & 6.03 & $<.001$ & & \\
\hline AvRAI & 0.26 & 0.05 & 4.94 & $<.001$ & 1.29 & {$[1.17,1.44]$} \\
\hline RAI $\Delta$ & 0.11 & 0.06 & 1.84 & .065 & 1.12 & {$[0.99,1.26]$} \\
\hline \multicolumn{7}{|c|}{ Step 2: $-2 \mathrm{LL}=247.26, \mathrm{AIC}=265.26, \chi^{2}(3)=23.80, p<.001$, Nagelkerke $R^{2}=.39$} \\
\hline Threshold 1|2 & 2.89 & 1.51 & 1.91 & .056 & & \\
\hline Threshold $2 \mid 3$ & 4.13 & 1.41 & 2.94 & .003 & & \\
\hline Threshold $3 \mid 4$ & 6.51 & 1.44 & 4.53 & $<.001$ & & \\
\hline Threshold $4 \mid 5$ & 9.24 & 1.57 & 5.87 & $<.001$ & & \\
\hline AvRAI & 0.19 & 0.06 & 3.39 & $<.001$ & 1.21 & {$[1.09,1.35]$} \\
\hline RAI $\Delta$ & 0.08 & 0.06 & 1.35 & 176 & 1.08 & {$[0.96,1.22]$} \\
\hline Relatedness need satisfaction & 0.29 & 0.17 & 1.75 & .080 & 1.34 & {$[0.97,1.86]$} \\
\hline Competence need satisfaction & 0.58 & 0.20 & 2.89 & .004 & 1.79 & {$[1.21,2.67]$} \\
\hline Autonomy need satisfaction & 0.50 & 0.19 & 2.62 & .009 & 1.66 & {$[1.14,2.43]$} \\
\hline
\end{tabular}

${ }^{a}$ Confidence intervals for the estimates of proportional odds ratios were obtained by profiling the likelihood function. 
indicate that the characteristics of the study, such as the level of the autonomy given to the students and enhancement of the relatedness between students and professors, are more important in predicting satisfaction with the studies than the self-determined forms of motivation.

We also performed a hierarchical ordinal regression (proportional odds model with logit link function) to predict students' certainty in the study choice (considered as an ordinal outcome variable) with two steps in which the same predictors as in the hierarchical linear regression model for predicting students' satisfaction with the studies were entered in the regression model. Results are shown in Table 5. In Step 1 , the predictive value of the avRAI and RAI $\Delta$ was statistically significant, however, only avRAI reached statistical significance, with proportional odds ratio 1.29, meaning that with an increase in avRAI by 1 , the odds for moving from one certainty category to the next category in a row was multiplied by 1.29. In Step 2 of the ordinal regression model, variables related to the basic psychological need satisfaction that were entered in the model statistically significantly improved the prediction. The avRAI retained its significant predictive role, and the competence and autonomy need satisfaction were found to be additional statistically significant predictors explaining the certainty in the study choice. On average, the students who showed more self-determined motivation and higher satisfaction of the competence and autonomy needs also expressed higher certainty that their choice of the study has been correct.

\section{Discussion}

In this study, we explored different forms of university students' academic motivation as explained on the SDT motivational continuum (Ryan \& Deci, 2000a, 2000b, 2017) and their stability across one academic year. We were also interested in the relationship of well- and less-internalized forms of academic motivation and the relative autonomy index (RAI) with students' satisfaction of their psychological needs in the academic context. The last aim was to examine the contributions of autonomous motivation and psychological need satisfaction to the prediction of students' satisfaction with the study and their certainty of study choice.

As hypothesized, we found that all forms of academic motivation (i.e. amotivation, external regulation, introjected regulation, identified regulation, and the three forms of intrinsic motivation) remained highly stable within one academic year in a Slovenian university context. The findings accord with those of the two previous longitudinal studies done within the US and Croatian study context (Fazey \& Fazey, 1998; Muller \& Palekčić, 2005b). On average, students showed above mean levels of all forms of extrinsic and intrinsic motivations and low levels of amotivation, confirming the findings of our previous cross-sectional study (Puklek Levpušček \& Podlesek, 2017). It is important to note that the two well-internalized forms of 
motivation (identified regulation, IM to know) were rated the highest among students. This result indicates that our participants have had high personal interest in their study and a well-shaped goal of obtaining deep knowledge in their study discipline. However, the next most expressed motivation was external regulation, which is the least autonomous type of extrinsic motivation. The items on the AMSC 28 questionnaire (Vallerand et al., 1992), which was used in the present study to measure academic motivation, describe external regulation with the reasons for the study, such as "to find a high-paying job later on", "to obtain a more prestigious job later on", "to have 'a good life' later on", and "to have a better salary later on". The results, therefore, indicate that, on average, students showed an inherent interest in the study they chose, but, on the other hand, they were also motivated by external contingencies, and perceived their study as a way to a financially good life and a high-status job. The interlace of both extrinsic and intrinsic motives in students' academic and career goal-setting was also observed in the study on career goals of Slovenian university students (Puklek Levpušček, Rauch, \& Komidar, 2018). Although students considered intrinsic career goals (e.g., gaining new skills and knowledge, having interesting and challenging work, and contributing to society) as more important than the extrinsic career goals (e.g., high income, career success, power and influence in an organizational setting, and employment security), the latter were also perceived as substantially relevant in the career development. Why do students highly value two opposite motivational tendencies: intrinsic (autonomous) on one hand, and extrinsic (controlled) on the other? Lepper, Corpus, and Iyengar (2005) proposed that it is more adaptive for students' future outcomes and opportunities to "seek out activities that they find inherently pleasurable while simultaneously paying attention to the extrinsic consequences of those activities in any specific context" (p. 191). In fact, controlled motivation may facilitate goal progress, at least in a short-term period, especially in environments, such as study and work, which strongly emphasize the achievement of particular goals (Koestner et al., 2008).

The correlations between academic motivation dimensions and students' satisfaction of competence, autonomy and relatedness in the study context were quite weak and did not support our hypothesis. However, students' absence of any motivation (i.e., amotivation) was statistically significantly negatively related to students' satisfaction of the competence and autonomy need in the study setting. It was also negatively related to their certainty of study choice and satisfaction with their study. It seems that students' passive position toward study and doing study duties automatically without any particular goals go hand in hand with negative or less favourable perceptions of the study environment and their doubts in the right decision about the study choice. Students with higher autonomous motivational orientation (measured by the average RAI), on the other hand, reported higher psychological need satisfaction and had higher scores on the two study outcomes. This study thus showed that the relative autonomy index (RAI), which integrates the information from different motivational subscales and indicates pure expression of 
students' self-determined motivation (Fortier et al., 1995), proved to be a better indicator of the relationship between academic motivation and psychological need satisfaction in education and study adjustment (as proposed by SDT) than separate SDT motivational dimensions. Similarly, Sheldon et al. (2017) found that using a single RAI score is valid and efficient way of describing the overall motivation of an individual and that the associations between the RAI scoring method and well-being outcomes may be stronger (or at least equally strong) than the associations of wellbeing outcomes with the single subscales that comprise the RAI.

The SDT proposed that the core propensity of human nature is to show interest in learning and motivation to develop one's knowledge. Such self-determined motivation may lead to better study engagement and performance. Our study confirmed this assumption - more autonomous motivational orientation was a statistically significant predictor of students' satisfaction with the study and decidedness about the study. Additionally, positive change in autonomous motivation significantly contributed to the prediction of satisfaction with the study. However, high-quality learning happens when students' capacities for wellinternalized forms of academic motivation are accompanied by learning contexts that support student's basic psychological needs (e.g., Niemiec \& Ryan, 2009). As confirmed in the present study, students' perceptions of possibilities of free selfexpression, decision-making and volition in the academic settings (autonomy) and their feelings of good relationship with study colleagues and teachers (relatedness) are even more important predictors of the study satisfaction than students' level of autonomous motivation. The average RAI, as well as the change in the RAI across Waves 1 and 2, lost a great deal of their prediction power when psychological needs satisfaction was entered in the regression model. Similarly, students' level of autonomous motivation statistically significantly contributed to students' belief that their choice of study was right. However, when the three basic psychological needs were entered into the model, the prediction of the study decidedness improved significantly. The two best predictors of study choice certainty were students' satisfaction of competence need and need for autonomy in the study context. This result shows that the importance of different motivational needs may alter according to the context of an individual's activity, task or belief. The certainty of study choice is an individual belief that may be enhanced by students' perception of task efficiency and autonomous decisions in the study context and not so much by establishing and maintaining close relations with teachers and study colleagues. However, feelings of relatedness may be especially important in enhancing activities, tasks and beliefs that are primarily social in nature (Deci \& Ryan, 2002; Karimi \& Sotoodeh, 2019), and in promoting higher satisfaction with the study, as shown in our study.

Given the correlational nature of our study and the limitation to the use of selfreport measures, the implications of our findings should be considered tentative. Only 2nd phase students from one university were included in the study, and the sample of students who completed the online questionnaires twice was relatively 
small. The attrition rate from Wave 1 to Wave 2 was relatively large, even though we found that the group of those who quit the study did not differ in gender, age, average study grade, and academic motivation from those who participated twice. Furthermore, students were followed only for a single academic year. To allow for greater changes in their motivation, our study should last longer and possibly cover several academic years. The motivation of students toward the end of their studies might be different from the one in the first year. Also, satisfaction of basic psychological needs in the study context and satisfaction with the study were considered to be general (related to the study as a whole), but it is possible that students would provide different responses with regard to different courses, and that the relations between different constructs would be different (perhaps stronger) if students assessed the constructs with regard to a single course. Furthermore, psychological needs were only measured once (at the end of the study year), as students needed to look back on how their needs were fulfilled during the academic year, so we can only speak about the relations between the studied variables and cannot consider some of them as being factors of the other ones.

Nonetheless, our study showed that it is important to search ways how to create a learning environment that responds to student's individual study needs. Studentcentred learning is a recent popular perspective on learning which emphasizes active and deep learning, learner's autonomy, responsibility, and accountability, codependence and mutual respect between the teacher and the learner, and a continuing reflexive evaluation of one's learning and teaching process (Cannon \& Newble, 2000; Lea, Stephenson, \& Troy, 2003). One of the key elements of student-centred learning is recognising what students are motivated for and searching ways how to balance students' active engagement in tasks and teacher's thoughtful stimulation and guidance of students through the subject matter (Maclellan, 2008). A powerful learning environment should enable students to take full responsibility for the construction of their knowledge in a learning environment that is challenging and safe. Students must have an opportunity to freely express their ideas and views about the subject matter and should not fear of possible mistakes during their learning. A high quality-learning environment encourages students to work independently while teachers concurrently offer them clear guidance and support and take a metacognitive (monitoring) role in students' pursuing learning goals and judging their progress (Elen, Clarebout, Léonard, \& Lowyck, 2007). Such an environment might lead to greater satisfaction with the studies and enhance intrinsic motivation and authentic interest in the study field. 


\section{References}

Ames, C. (1992). Classrooms. Goal, structures, and student motivation. Journal of Educational Psychology, 84, 261-271.

Bandura, A. (1997). Self-efficacy: The exercise of control. New York: Freeman.

Burton, K. D., Lydon, J. E., D'Alessandro, D. U., \& Koestner, R. (2006) The differential effects of intrinsic and identified motivation on well-being and performance: Prospective, experimental, and implicit approaches to self-determination theory. Journal of Personality and Social Psychology, 91, 750-762.

Cannon, R., \& Newble, D. (2000). A handbook for teachers in universities and colleges. A guide to improving treaching methods. Oxon: Routledge Falmer.

Carbonneau, N., Vallerand, R. J., \& Lafrenière, M.-A. K. (2012). Toward a tripartite model of intrinsic motivation. Journal of Personality, 80, 1147-1177.

Cokley, K. O., Bernard, N., Cunningham, D., \& Motoike, J. (2001). A psychometric investigation of the academic motivation scale using a United States sample. Measurement and Evaluation in Counseling and Development, 34, 109-119.

Deci, E. L. (1975). Intrinsic motivation. New York: Plenum.

Deci, E. L., \& Ryan, R. M. (1985). Intrinsic motivation and self-determination in human behaviour. New York: Plenum.

Deci, E. L., \& Ryan, R. M. (2002). The paradox of achievement: The harder you push, the worse it gets. In J. Aronson (Ed.), Improving academic achievement (pp. 61-87). Amsterdam: Academic Press.

Deci, E. L., Ryan, R. M., Gagne, M., Leone, D. R., Usunov, J., \& Kornazheva, B. P. (2001). Need satisfaction, motivation, and well-being in the work organizations of a former Eastern Bloc country: A cross-cultural study of self-determination. Personality and Social Psychology Bulletin, 27, 930-942.

Eccles, J. (1983). Expectancies, values, and academic behaviors. In J. T. Spence (Ed.), Achievement and achievement motives: Psychological and sociological approaches (pp. 75-146). San Francisco, CA: W. H. Freeman.

Elen, J., Clarebout, G., Léonard, R., \& Lowyck, J. (2007). Student-centred and teachercentred learning environments: What students think. Teaching in Higher Education, 12, 105-117.

Fairchild, A. J., Horsta, S. J., Finneya, S. J., \& Barron, K. E. (2005). Evaluating existing and new validity evidence for the Academic Motivation Scale. Contemporary Educational Psychology, 30, 331-358.

Fazey, D., \& Fazey, J. (1998). Perspectives on motivation: The implications for effective learning in higher education. In S. Brown, S. Armstrong, \& G. Thompson (Eds.), Motivating students (pp. 59-72). London: SEDA: Staffand Educational Development Series. 
Fortier, M. S., Vallerand, R. J., \& Guay, F. (1995). Academic motivation and school performance: Toward a structural model. Contemporary Educational Psychology, 20, 257-274.

Guay, F., Morin, A. J. S., Litalien, D., Valois, P., \& Vallerand, R. J. (2015). Application of exploratory structural equation modeling to evaluate the Academic Motivation Scale. The Journal of Experimental Education, 83, 51-82.

Guay, F., Ratelle, C. F., Roy, A., \& Litalien, D. (2010). Academic self-concept, autonomous academic motivation, and academic achievement: Mediating and additive effects. Learning and Individual Differences, 20, 644-653.

Harter, S. (1981). A new self-report scale of intrinsic vs. extrinsic orientation in the classroom: Motivational and informational components. Developmental Psychology, 17, 300-312.

Karimi, S., \& Sotoodeh, B. (2019). The mediating role of intrinsic motivation in the relationship between basic psychological needs satisfaction and academic engagement in agriculture students. Teaching in Higher Education, doi:10.1080/13562517.2019. 1623775

Koestner, R., Otis, N., Powers, T. A., Pelletier, L., \& Gagnon, H. (2008). Autonomous motivation, controlled motivation, and goal progress. Journal of Personality, 76, 12011230.

Kusurkar, R. A., Ten Cate, T. J., Vos, C. M. P., Westers, P., \& Croiset, G. (2013). How motivation affects academic performance: A structural equation modelling analysis. Advances in Health Sciences Education, 18, 57-69.

Lea, S. J., Stephenson, D., \& Troy, L. (2003). Higher education students' attitudes to student centred learning: Beyond 'educational bulimia'? Studies in Higher Education, 28, 321334.

Lepper, M. R., Corpus, J. H., \& Iyengar, S. S. (2005). Intrinsic and extrinsic motivational orientations in the classroom: Age differences and academic correlates. Journal of Educational Psychology, 97, 184-196.

Maclellan, E. (2008). The significance of motivation in student-centred learning: A reflective case study. Teaching in Higher Education, 13, 411-421.

Müller, F. H., \& Palekčić, M. (2005a). Bedingungen und Auswirkungen selbstbestimmt motivierten Lernens bei kroatischen Hochschulstudenten [Conditions and effects of self-determined learning motivation in Croatian students]. Empirische Pädagogik, 19, 134-165.

Müller, F. H., \& Palekčić, M. (2005b). Continuity of motivation in higher education: A threeyear follow-up study. Review of Psychology, 12, 31-43.

Niemiec, C. P., \& Ryan, R. M. (2009). Autonomy, competence, and relatedness in the classroom. Applying self-determination theory to educational practice. Theory and Research in Education, 7, 133-144. 
Puklek Levpušček, M., \& Podlesek, A. (2017). Veljavnost in zanesljivost Lestvice akademske motivacije na vzorcu slovenskih študentov [Validity and reliability of the Academic Motivation Scale in a sample of Slovenian students]. Psihološka obzorja, 26, 10-20.

Puklek Levpušček, M., Rauch, V., \& Komidar, L. (2018). Individuation in relation to parents as a predictor of career goals and career optimism in emerging adults. Scandinavian Journal of Psychology, 59, 146-156.

Ratelle, C. F., Guay, F., Vallerand, R. J., Larose, S., \& Senécal, C. (2007). Autonomous, controlled, and amotivated types of academic motivation: A person-oriented analysis. Journal of Educational Psychology, 99, 734-746.

Ryan, R. M., \& Connell, J. P. (1989). Perceived locus of causality and internalization: Examining reasons for acting in two domains. Journal of Personality and Social Psychology, 57(5), 749-761.

Ryan, R. M., \& Deci, E. L. (2000a). Self-determination theory and the facilitation of intrinsic motivation, social development, and well-being. American Psychologist, 50, 68-78.

Ryan, R. M., \& Deci E. L. (2000b). Intrinsic and extrinsic motivations: Classic definitions and new directions. Contemporary Educational Psychology, 25, 54-67.

Ryan, R. M., \& Deci, E. L. (2017). Self-determination theory: Basic psychological needs in motivation development and wellness. New York, NY: Guilford Press.

Schunk, D. H., \& Pajares, F. (2001). The development of academic self-efficacy. In A. Wigfield \& J. S. Eccles (Eds.), Development of achievement motivation (pp. 15-31). San Diego: Academic Press.

Sheldon, K. M., Osin, E. N., Gordeeva, T. O., Suchkov, D. D., \& Sychev, O. A. (2017). Evaluating the dimensionality of self-determination theory's relative autonomy continuum. Personality and Social Psychology Bulletin, 43, 1215-1238.

Sun, Y., Ni, L., Zhao, Y., Shen, X. L., \& Wang, N. (2018). Understanding students' engagement in MOOCs: An integration of self-determination theory and theory of relationship quality. British Journal of Educational Technology, 50(6), 3156-3174. doi:10.1111/bjet.12724

Vallerand, R. J., \& Bissonnette, R. (1992). Intrinsic, extrinsic, and amotivational styles as predictors of behavior: A prospective study. Journal of Personality, 60, 599-620.

Vallerand, R. J., Blais, M. R., Brière, N. M., \& Pelletier, L. G. (1989). Construction et validation de l'Échelle de Motivation en Éducation. Revue Canadienne des Sciences du Comportement, 21, 323-349.

Vallerand, R. J., Pelletier, L. G., Blais, M. R., Brière, N. M., Senécal, C. B., \& Vallières, E. F. (1992). The Academic Motivation Scale: A measure of intrinsic, extrinsic, and amotivation in education. Educational and Psychological Measurement, 52, 1003-1017.

Vansteenkiste, M., Lens, W., \& Deci, E. L. (2006). Intrinsic versus extrinsic goal contents in self-determination theory: Another look at the quality of academic motivation. Educational Psychologist, 41, 19-31. 


\title{
Povezanost akademske motivacije, zadovoljenja psiholoških potreba u obrazovanju i zadovoljstva studenata studijem
}

\begin{abstract}
Sažetak
Motivacija studenata predstavlja važan čimbenik školskoga postignuća. Ovim je istraživanjem ispitana akademska motivacija studenata tijekom akademske godine i njezin odnos sa zadovoljenjem psiholoških potreba u kontekstu studiranja te s akademskom prilagodbom. Teorijski okvir ovog istraživanja predstavlja teorija samoodređenja (SDT) Decija i Ryana. U obje su točke mjerenja sudjelovala 124 studenta. Na početku akademske godine studenti su ispunili Skalu akademske motivacije, verziju za studente (AMS-C 28), a sedam mjeseci kasnije odgovorili su na pitanje o svojoj sigurnosti izborom studija te ponovno ispunili AMS-C 28. Pored toga, procijenili su stupanj zadovoljenosti psiholoških potreba (za autonomijom, kompetencijom i povezanošću) u tekućoj akademskoj godini te svoje zadovoljstvo studijem. Rezultati su pokazali da su svi oblici akademske motivacije (raspoređeni po motivacijskom kontunuumu SDT-a) tijekom akademske godine ostali vrlo stabilni. Viša autonomna motivacijska orijentacija bila je povezana $s$ većim percipiranim zadovoljenjem psiholoških potreba te je bila značajan prediktor zadovoljstva studenata studijem i sigurnosti u izbor studija. Kada je zadovoljenje psiholoških potreba studenata u tekućoj akademskoj godini uneseno u regresijski model, predviđalo je zadovoljstvo studijem i sigurnost u izbor studija povrh autonomne motivacije studenata. Istraživanje je uputilo na važnost stvaranja okruženja za učenje koje je responsivno na psihološke potrebe studenata vezane uz studij.
\end{abstract}

Ključne riječi: tercijano obrazovanje, akademska motivacija, osnovne psihološke potrebe, zadovoljstvo studijem, sigurnost u izbor studija, regresijska analiza

Primljeno: 1.3.2019. 